\title{
In vitro assembly of xenotropic murine leukemia virus-related virus CA-NC protein
}

\author{
Romana Hadravová', Jitka Štokrová1, Michal Doležal', Iva Pichová', Tomáš Ruml², Michaela Rumlová1* \\ From 15th International Conference on Human Retroviruses: HTLV and Related Viruses \\ Leuven and Gembloux, Belgium. 5-8 June 2011
}

Using in vitro expression/assembly system we studied the formation of virus-like particles Xenotropic Murine Leukemia Virus-related virus (XMRV). XMRV is novel human gammaretrovirus discovered in association with human prostate tumors. The genome organization is typical for gammaretroviruses consisting of two overlapping ORFs coding for Gag-Pro-Pol and Env polyproteins. The predicted Gag polyprotein consists of 536 amino acids and is separated from the Pro-Pol sequence by UAG stop codon.

Based on the amino acids similarities between MLV and XMRV Gag polyproteins, we designed primers bordering CA-NC region of Gag. Resulting PCR fragment was cloned into pET22b vector for expression of CA-NC in E. coli. We found that purified XMRV full-length CANC, starting with the conserved proline residue at the $\mathrm{N}$-terminus of $\mathrm{CA}$, was not able to assemble into particles. However, a modification of the $\mathrm{N}$-terminus of CANC (modCANC) enabled formation of spherical particles. Moreover, the negative staining of the in vitro assembled particles of XMRV modCANC revealed different organization of protein layers in comparison to CA-NC of M-PMV.

\section{Author details \\ ${ }^{1}$ Department of Biochemistry, Institute of Organic Chemistry and Biochemistry Czech Academy of Sciences, Prague, Czech Republic. ${ }^{2}$ Department of Biochemistry and Microbiology, Institute of Chemical Technology, Prague, Czech Republic.}

Published: 6 June 2011

doi:10.1186/1742-4690-8-S1-A236

Cite this article as: Hadravová et al:: In vitro assembly of xenotropic murine leukemia virus-related virus CA-NC protein. Retrovirology 20118 (Suppl 1):A236.

\footnotetext{
* Correspondence: rumlova@uochb.cas.cz

${ }^{1}$ Department of Biochemistry, Institute of Organic Chemistry and

Biochemistry Czech Academy of Sciences, Prague, Czech Republic

Full list of author information is available at the end of the article
}

Submit your next manuscript to BioMed Central and take full advantage of:

- Convenient online submission

- Thorough peer review

- No space constraints or color figure charges

- Immediate publication on acceptance

- Inclusion in PubMed, CAS, Scopus and Google Scholar

- Research which is freely available for redistribution
C Biomed Central
C Biomed Central

(c) 2011 Hadravová et al; licensee BioMed Central Ltd. This is an open access article distributed under the terms of the Creative Commons Attribution License (http://creativecommons.org/licenses/by/2.0), which permits unrestricted use, distribution, and reproduction in any medium, provided the original work is properly cited. 